alive these echini were of a brilliant vermilion colour. Salenia pattersoni spec. nov., is described as the most exquisitely coloured of the living Salenidæ, thus far found the test was of a light cream colour, as well as the shafts of the primary spines. These are banded with a brilliant vermilion, the two colours nearly equally divided. The secondary spines are also cream-coloured, but separated at the base by dark violet Iines which extend from the apical to the actinal system. Similar dark violet lines separate the genital and ocular plates. Conoclypus sigsbei is described as a magnificent species; by far the most striking sea-urchin which $A$. Agassiz had ever seen. The first time it was seen the dredge brought up half a dozen of the huge, brilliant lemon-coloured specimens. All these species, as well as the remarkable Periaster limicolia, are figured from photographs. - Count Pourtalés describes a number of new or rare forms of corals. As far as our present knowledge goes, he writes, no sea-bottom can rival in abundance of deep-sea corals the West Indian. It is not at all unfrequent for a single cast of the dredge to bring up a dozen different species represented by more or less numerous specimens of each. A very young specimen of Holopus was dredged from a depth of 100 fathoms. It has been sent for study to Sir Wyville Thomson; but a beautiful figure by A. Agassiz is here given. Several new species of. Antedon are described by Pourtalés. A large number of new. species and two new genera of ophiuroids are described by Theodore Lyman. The descriptions are accompanied by excellent figures.

UNited States Fish COMmission. - Messrs. G. Brown Goode and Tarleton H. Bean give an account of some fifty species of fishes from the east coast of the United States, some of which are new to science and all of which are new to the fauna of that portion of the American States. Among the more interesting of the new forms may be mentioned Phycis chesteri, the largest specimens measured without the tail about eight inches in length; they were taken off Cape Ann. A new species of Dr. Günther's genus Haloporphyrus was taken on the outer edge of Le Have Bank at a depth of 400 to 500 fathoms. Two specimens of the rare Remoropsis brachyptera (Lowe) Giil, were obtained : one was found clinging to the side of a sword-fish, harpooned in the channel south-west of George's Bank, and the other on the deck of a Halibut trawler fishing to the north-east of George's Bank, at a time when sword-fish were being taken on the trawls. A specimen of Nemichthys scolopaceus was taken alive from the stomach of a cod caught on the same bank. Amia calva is reported from St. John's River, Florida, and from Spruce Creek, a tributary of Halifax River, about lat. $28^{\circ}$. Its range has not hitherto been recognised south of Charlestown, South Carolina, from whence Garden sent specimens to Linnæus (American Journal of Science and Alrts, January, 1879).

AMERICAN CEDOGONIACEA,-Dr. V. B. Wittrock bas just published a revision of the species of Edogoniacex rownd in America, as far as they are known (Botaniska Notiser utgifne af $\mathrm{O}$. Nordstedt, November, 1878 ). The list contains twenty-three species belonging to the genus CEdogonium, and eight belonging to the genus Bulbochate. Of these, nine are found in Greenland, five in Pennsylvania, one in California, five in Mexico, three in the West Indies, one in Venezuela, one in Bolivia, and seven in Brazil. It would seem very certain that this number constitutes but a small part of the species which will by further investigations be discovered; still it enables the author to draw, with a considerably bigh degree of probability, the following conclusions:-1. That the oedogoniaceous veretation of America differs but little from that of the European. 2. That the species found towards the more rorthern portion of this area are perfectly identical with t.ose to be met with in Northern Europe, while the species met with in the more southern portion of the same area are either species quite different from those met with in Europe, or, at most, extreme varieties of European forms. Only one of the South American species forms an exception to this (QEdogonium crispum (Hass.), Wittr.), which would seem to be nearly a cosmopolitan. 3. That the genus Bulbochæte bas in America, as in Europe, most of its species indigenous to the cold temperate or arctic zone. Of the eight species known from America, five are natives of Greenland.

Chemico-Agricultural Stations in ItALY,Stations for the scientific observations of subjects connected with agriculture in its widest sense, have now been for several years established throughout Italy. These are under the general control of a Minister of Agriculture. We have lately received the reports (Atti) of the stations at Rome and Palermo, contributed by Prof. J. G. Briosi ; they have, as might be expected, mostly to do with the subject of the diseases of the vine and the olive. Among the more important of these reports are the following: On the Phytoptus of the Vine (Phytoptus vitis), with figures; an account of the Marciume of the Vine (Albinia wockiana); with figures; on a Fungoid Disease attacking Lemons (Fusisporium limoni), with figures. At Messina a lemon-tree, in good condition, of fair size, will, it is reckoned, produce about 2,000 ripe fruit each year. These fruits are sold at from twenty to forty lire the thousand, according to size and quality, so that a lemon orchard is of great value, and a good deal of distress has been caused by the destruction of the lemon crops by this disease.

ASPARAGIN IN PLANTS.-The physiological rôle and distribution of asparagin in the plant kingdom have been lately studied by Herr Borodin (Botanische Zeitung, $5 \mathrm{r}$ and 52,1878 ). He states, as the result of his researches, that whenever a vigorous part of a plant becomes poor in nonnitrogenous substances, asparagin occurs as a product of decomposition, and accumulates. This may be explained in either of two ways : either the presence of non-nitrogenous matters hinders the decomposition of albumen, while these alone are decomposed; or (conversely) in life albumen is always decomposed and asparagin constantly formed, but where carbohydrates are present albumen is regenerated, and it is only where these are deficient that asparagin accumulates. The former bypothesis supposes different processes of decomposition in life according as carbohydrates are present or not; Herr Borodin thinks it therefore the more improbable, and adopts the other, doing so the more readily that the regeneration of albumen from asparagin and carbohydrates certainly occurs, and is necessary for the transference of the albuminous matters. Not all carbohydrates are adapted for regeneration of albumen from asparagin, and therefore asparagin may accumulate even when carbohydrates are present. Such unsuitable carbohydrates are starch and the oils, whereas glucose is the suitable form.

\section{THE PIC DU MIDI OBSERVATORY}

$\mathrm{R}$ readers may remember that early in the year General de Nansouty, the hardy director of the Pic du Midi Meteorological Observatory, was cut off from communication with the world below, the severe weather having so affected the telegraph as to prevent it from acting. Fears were entertained for the General's safety, and $M$. Albert Tissandier resolved to organise a party for the ascent of the $P i c$ and the succour of the veteran observer. An interesting account of this ascent appears in La Nature, to which we are indebted for the accompanying illustrations. The snow-storm having somewhat abated at Bagnères-de-Bigorre on January 9, M. Tissandier resolved to attemft the Pic next day, in company with three of General Nansouty's usual guides. 
They set out at 9 A.M. on the roth, and in spite of the deep snow and fallen avalanches, the ascent was at first not difficult. After equipping themselves for snow work at some huts occupied only in summer, the ascent was begun in earnest. The weather was grey and uncertain, the temperature $0^{\circ}$ Cent., with a thick mist that prevented anything being seen beyond 300 metres. The snow became deeper and deeper as they advanced, and one of the guides went before to show the way, the others following the marks of his footsteps up the steep slope of the mountain side. Sometimes they were buried to the waist, and often they had to rest to recover breath. The ascent was slow and difficult, but they were often rewarded by the magnificent effects resulting from the slay of light upon the snowy landscape beneath, or of the clouds advancing majestically into the midst of the snows. After attaining an altitude of 6,000 feet, they had got over the steepest part of the slope. But now the weather changed, the wind rose, and mists more and more obscured the sky. Squalls of snow were driven into their faces, and seriously hindered their progress. Alongside the track heaps of snow showed where avalanches had recently fallen from the rocks above. The telegraph posts, 7 metres high, were often buried; five or six of them were even broken by the violence of the recent storms, and the wires were broken. The weather got worse as they ascended, and M. Tissandier had all the symptoms of mountain-sickness, I which he had not experienced before, even when ascending Mont Blanc. At last, however, the summit was reached, and, as might be expected, General de Nansouty gave the party a warm reception. A glorious fire and an excellent dinner soon set $M$. Tissandier all right again.

a. The establishment of the General is far from being luxurious, M. Tissandier tells us; although none of the "1sual necessaries of life are wanting, one is struck with the devotion which impels him, for the sole purpose of advancing science to accept an existence so isolated, so primitive, and that during eight months of the year.

The observatory of the Pic du Midi is most picturesque. We enter first a passage with glass doors at the sides, in order to protect as much as possible from the violence of the wind and the gusts of snow. The telegraphic office is at the bottom. A respectable provision of wood furmishes this passage ; a few hens inhabit it ; one of them was slaughtered in M. Tissandier's honour. A room adorned with an immense freplace is next presented to the visitor's view; it is the vestibule. The guides sleep here on a camp bed, and have for messmates two dogs and two cats, presided over by the intendant, the faithful guardian of the observatory. All round this apartment, carefully arranged as on shipboard, may be seen a variety of provisions. The dining-room opens in this vestibule. In summer a separate part of the building is arranged for the reception of tourists, and a stable for horses is placed below the principal structure.

To the first storey there is no staircase, as there is no coom for it ; there is only a ladder with a knotted cord as balustrade. On ascending this, a small vaulted room is entered; a stove ruddy with fire heats the whole floor, and the cold of the outside is unknown in these hospitable chambers. The chief ornaments of this apartment consist of two sets of beds, one near the floor, used by $M$. Baylac, the second observer and devoted companion of General de Nansouty. Above is another bed, or rather shelf, to use the General's expression; this is for the use of visitors. It is reached by a ladder, and the mattress consists of an excellent sheepskin, on which, M. Tissandier declares, he slept so soundly, 8,000 feet above the sea, that he reluctantly left it on the morning after his arrival. On this first floor the General has a workroom in common with M. Baylac. This room is too small for the work which has to be done in it.

Everybody is up at daybreak; this is the inexorable order. The General then begins the day's observations. It is necessary to go outside to examine the thermometers and barometers, which are placed under a shelter con structed on a stone terrace. Every two hours, and oftener when the atmospheric conditions require it, tise observations are renewed, precisely recorded, and preserved with care. Thus the whole day is passed, night alone putting an end to the work. M. Tissandier bears testimony to the energy and patience of the courageous observer of the Pic du Midi in carrying on his work.

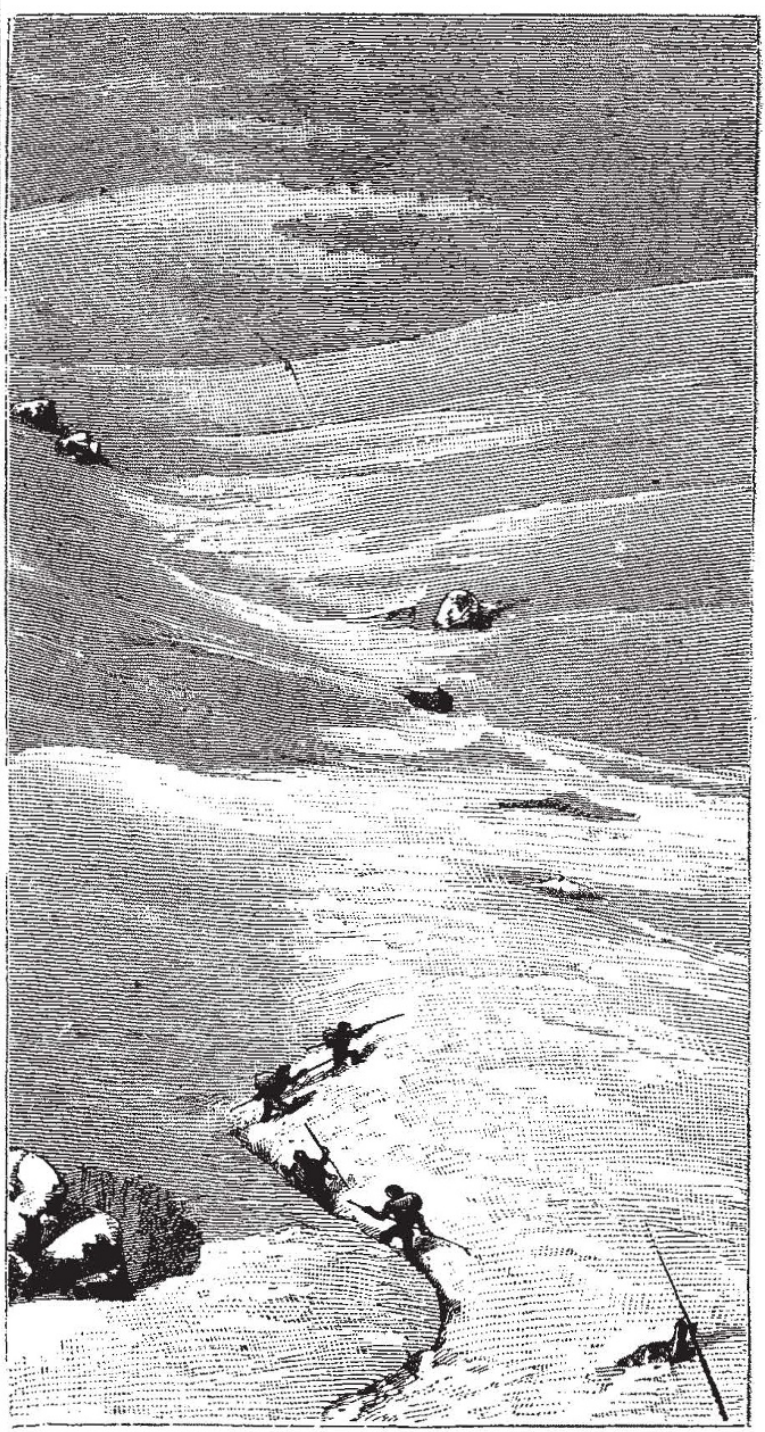

FIG. I.-Ascent of the Pic du Midi, January ro, 1879

Happily the rather too primitive arrangement of the General will soon be changed for the better, thanks to the generous donations of those who love and desire to advance science.

During the small amount of leisure which can be found between the hours of observation, General de Nansouty directs his companion in a great variety of labours. A very interesting herbarium of the flora of the high regions of the Pic du Midi has thus been formed. M. Tissandier admired some rare plants, such as Gentiana glacialis, Dapline charum, Salix herbacan, \&c. Mineralogical 


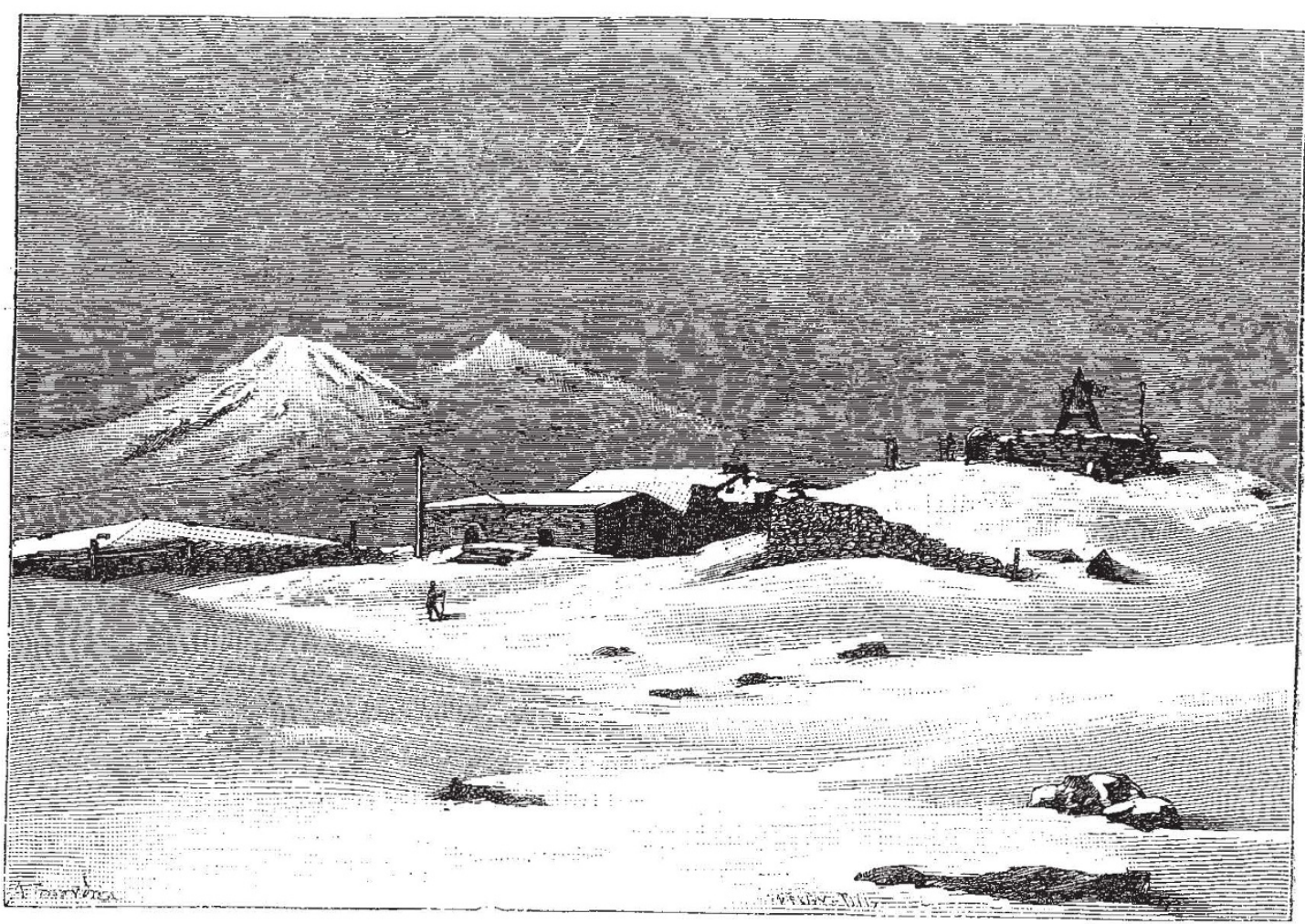

Fig. 2.-Observa'ory of the Pic ¿u Midi.

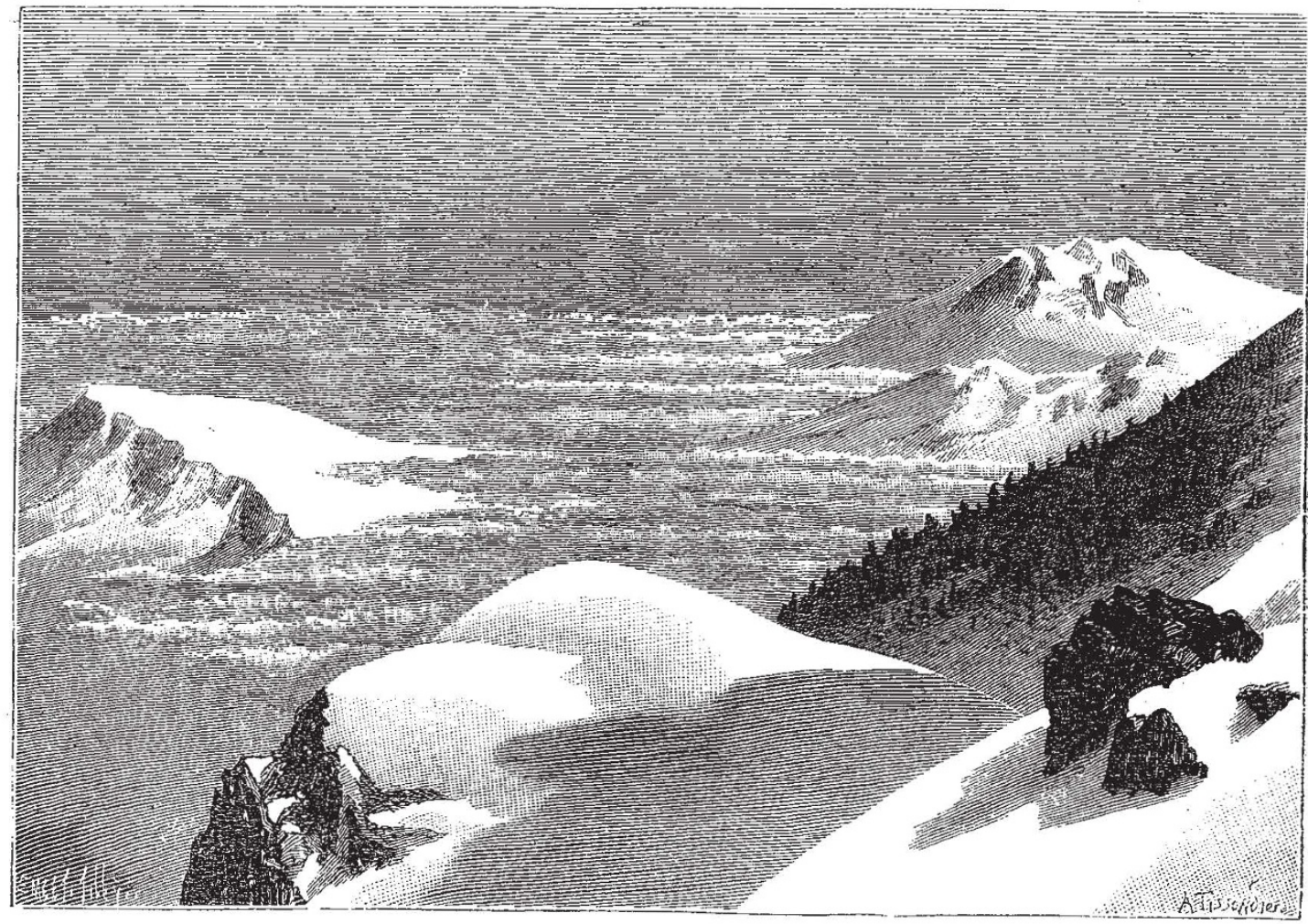

Fi: 3. The cres's of Penne Longue (Pic du M di) emerising ab:ve the cl:uds. 
specimens are also collected and arranged. Traps are $\mid$ The guides repaired the damage to the telegraph which also laid by M. Baylac, and thus a fine collection of had interrupted the General's communication for ten ermine skins has been formed.

days. M. Tissandier says rightly that these accidents

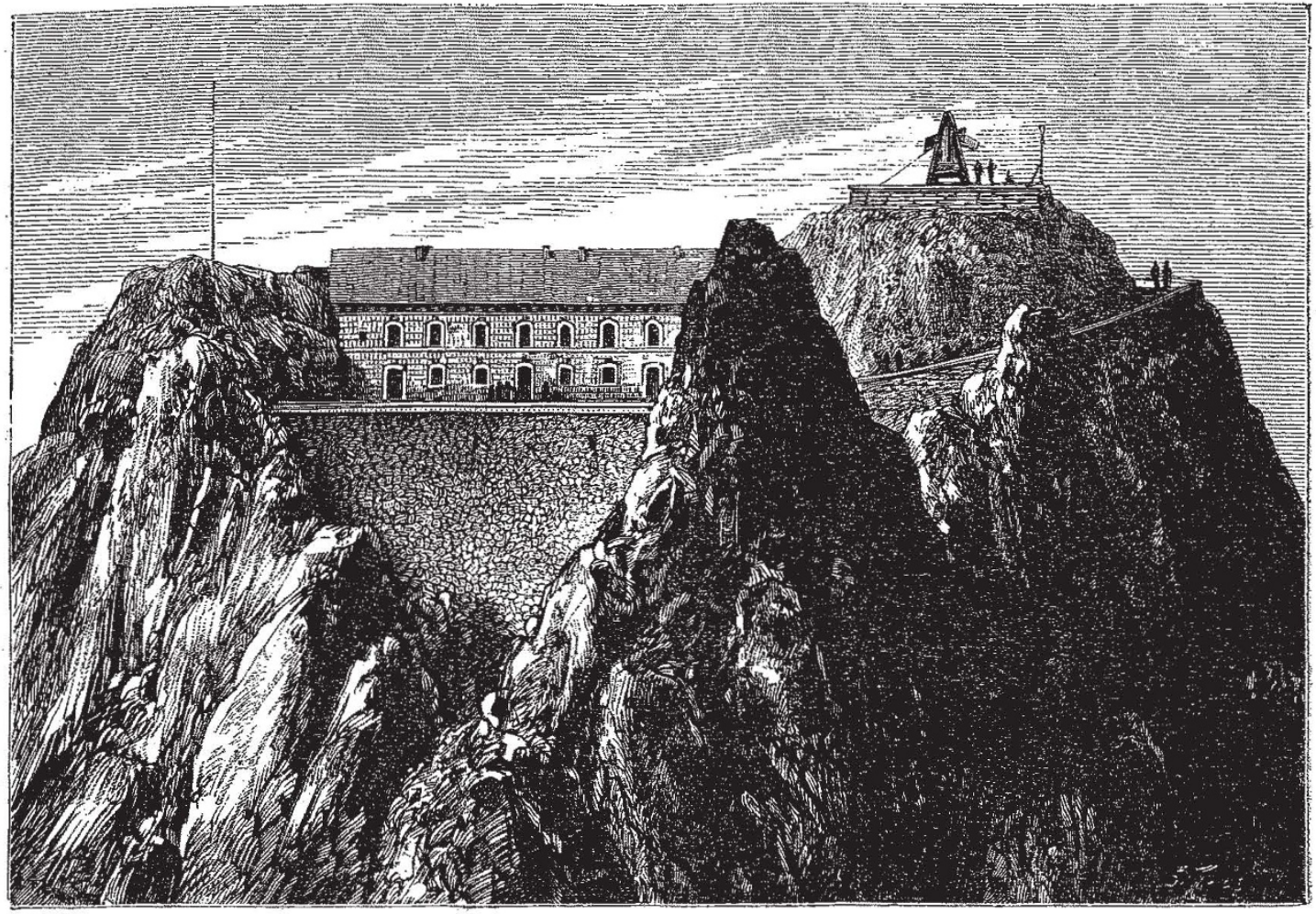

FIG. 4.-View of the New Obzervatory of the Pic ciu Midi, now building.

should not be allowed to bappen to a man who so/For at least a part of the distance between the summit generously devotes himself to the progress of a depart- and the plain the wires should be placed underground, ment of science that is of the greatest naticnal utility. and thus beyond the reach of injury from avalanches and
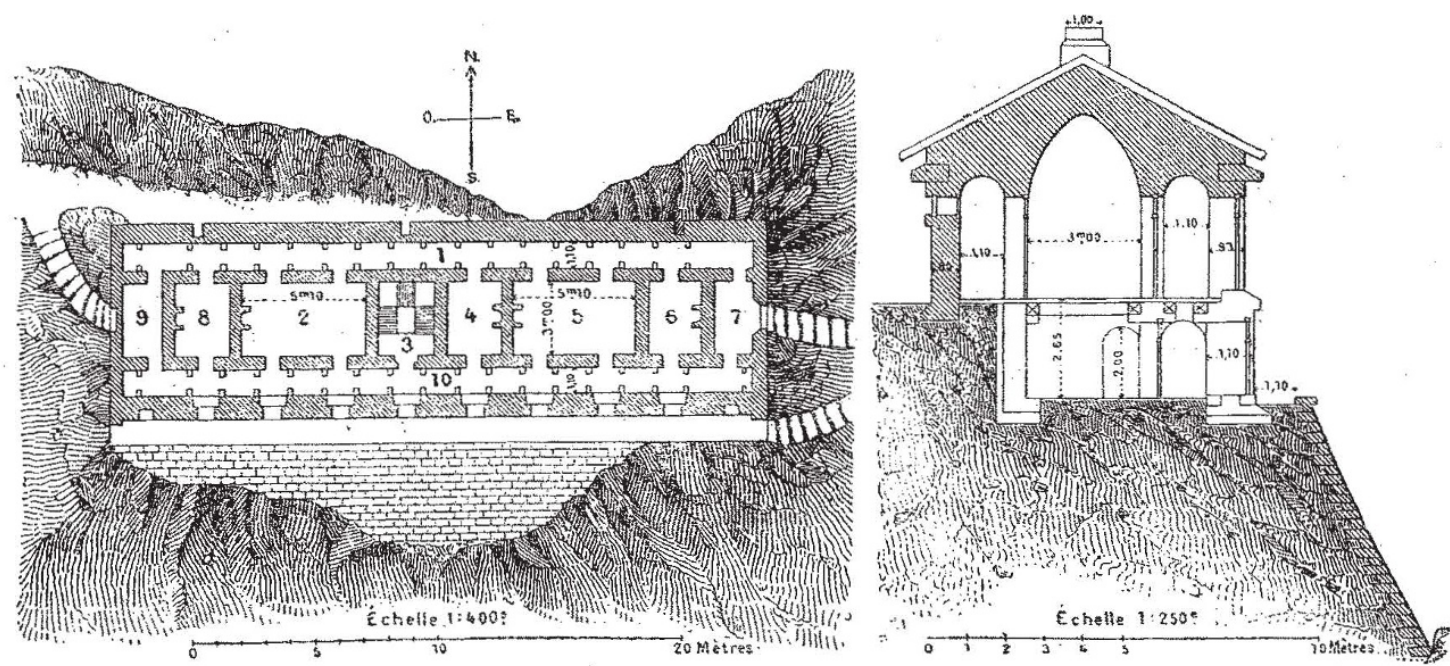

FIG 5.-Plan and section of the New Observatory. Plan of the first floor:- $x$, Passage, magazine; 2, Salon; 3 , Staircase; 4, Dining-room; 5 , Work. room; 6, Guest-chamber; - Telegraph; 8 and 9 , Bed-rooms. The ground-floor will be used for provisions.

storms. After M. Tissandier's visit, our readers may /good-bye on the 12 th, and during his descent took several remember, telegraphic communication was again inter- sketches. While it took him nine hours to make his rupted with the Pic. M. Tissandier bade the General ascent, he came down in four. 
Theimprovements contemplated by General de Nansouty comprise an entirely new and much more solid and durable structure at the very summit of the mountain. A few generous friends of science have come to his aid and placed in his hands the means of carrying out the execution of his enterprise. M. Bischoffsheim gives 15,000 francs, the Minister of Public Instruction and the Minister of Public Works each 10,000 francs, the Academy of Sciences 1,200 francs; and large sums have been given by various other societies and individuals while many smaller subscriptions, down to one franc, have been placed at the General's disposal. There is every reason to believe, that though the work will be much more costly than originally expected, it will be thoroughly and promptly completed.

Our illustration (Fig. 4) shows the new observatory as it will appear when the works are completed; it is at present half built. To the right is seen, perched on a platform, the shelter for the instruments of observation. In the centre is the dwelling-house, the arrangements of which will be seen in the plan, Fig. 5. To the left is the lightning-rod, intended to protect the structure from the lightning which so frequently strikes the summit of the Pic. This lightning-rod, with its cable, which plunges 500 metres lower down in Lak Oncet, has cost 2,800 francs. The excavation of the hollow in which the structure is built has cost 2,500 francs; so much of the building as has been raised, that is one half, has cost 22,000 francs. No doubt all the necessary funds will be forthcoming ; it is said that the Minister of Public Instruction will this year contribute another sum of 10,000 francs.

The example of General de Nansouty has already borne fruit in France. General Farre has installed an observatory at the foot of Infernet. In Provence a movement has been set on foot to place one on Mont Ventoux. With the fine observatory of the Puy de Dôme, France will possess an important net-work of high meteorological stations which cannot but render valuable services to a knowledge of atmospheric phenomena, and be of great practical value to national industry. Let us hope that in a very few months our own country will possess at least one of these lofty stations which the French Government, the French people, and French science think it their interest and duty to give substantial encouragement to.

\section{GEOGRAPHICAL NOTES}

Ar the meeting of the Geographical Society on Monday evening Sir Rutherford Alcock announced that the Earl of Dufferin had formally resigned the office of president in consequence of his appointment to the St. Petersburg embassy. Mr. Clements $\mathrm{R}$. Markham read a paper on the basin of the River Helmund and the smaller basin of the Abistada Lake, in Western Afghanistan, a region which is classic ground, and is the scene of many of the ancient Persian tales related in the pages of Ferdosi. Mr. Markham gave some interesting particulars respecting the formation of the river of Ghazni, which drains the eastern half of the remarkable isolated basin of Lake Abistada, on the east side of the western Sulimani Range. He afterwards read a paper by Lieut.-General Kaye, on the mountain passes leading to the valley of Bamian, based on that officer's recollections of his visit to the region north of Kabul, nearly forty years ago, supplemented by notes made at the time. With regard to the idols of Bamian, the limit of his journey, General Kaye mentions a curious fact, viz., that between the images and at their sides, peeping over their shoulders - and some even above their heads-were many caves in the cliffside on which they are cut, having intricate connecting approaches and galleries cut within the rock; these formed dwellings for many Bamianchis and also for some camp-followers of the British. The two papers were illustrated by the large diagram of Afghanistan which has just been constructed for the Society.
THE London Missionary Society have received letters down to October 17 from their mission at Ujiji, on Lake Tanganyika, which announce the death from apoplexy of the Rev. Mr. Thomson, the leader of the party after the Rev. Roger Price's departure. The Arabs, though well disposed, refuse to allow the missionaries to settle away from Ujiji. Mr. Hore, the scientific member of the mission, has taken several observations with the view of settling the position of Ujiji.

IN consequence of the prevailing ignorance on the subject, Mr. E. F. im Thurn, of Demerara, has begun to draw up some notes on the Indians of Guiana. In the first instalment he remarks that the main tests by which to distinguish the various tribes are language, geographical position, physical features, and customs, as expressed in their characters, habits, and legends. In applying these tests to the tribes of British Guiana he thinks it best to look first at their geographical position. British Guiana consists of three regions--the coast region nearest the sea, within that the forest region, and within that again the savannah region, which passes without break into the great savannahs of Brazil. The coast region, in the north, towards the sources of the Orinocco, is inhabited by the Warau Indians, and further south by the Arawacks, while here and there are settlements and families of the Caribisi, a term which appears to be not strictly synonymous with Caribs. The forest region is almost entirely inhabited by the Ackawois, with a very few Carabisi settlements scattered among them. The Savannah region is peopled by a large number of tribes. Beginning from the north towards the Orinocco, the chief are the Arecunas, Macusis, Wapianas, and Atorais. Further south are the Tarumas and Woiowais, and the small remnants of the Maopityans, or Frog Indians, and the Pianoghottos. Here and there travellers report the existence of other tribes, but these Mr. im Thurn maintains to be groups of hybrids between two tribes. Of the Maopityans-and the Pianoghottos nothing beyond a few details as to their peculiar personal appearance and manners is known, and of the Woiowais only the name is known. Mr. im Thurn next dwells at some length on the linguistic peculiarities of the other tribes mentioned, excepting the Tarumas, and he afterwards describes the way in which they most probably came into the positions they now occupy.

THE statue of Captain Cook, which has been erected in the Hyde Park, Sydney, was unveiled on February 25. The ceremony, which was of an imposing character, was performed by the Governor, Sir Hercules Robinson, in the presence of the Ministry, the public bodies of the city, detachments of the naval and military forces, and upwards of 20,000 spectators.

DR. EDWIN R. HEATH, of whose proposed exploration in South America we have already made mention, left New York on November 23, and reached Pará on December 19. He was to have taken a steamer up the Madeira on the $23 \mathrm{rd}$, and thence to Exaltacion or else across to Reyes, on the Beni River, where he proposed to spend some time in making collections and the necessary preparations for descending the river. He expected to obtain Greenwich time at San Antonio, the latitude and longitude of which is well established, and to work his longitudes by them until arriving at the Beni, where be intended to correct it by "lunars." With a good outfit and apparatus he was to take observations of latitude and longitude at every suitable opportunity, as also to make records of the thermometer, barometer, and boiling. points. After completing all his preparations at Reyes, and having his balsa properly constructed and equipped, he proposed to commit himself to the current, and take his chances of what might happen.

THE Minister of Public Instruction at Paris has received an interesting communication from Dr. Jules 